\title{
Evaluation of Changes in Quality of Life After Dental Treatment in Children
}

\section{Çocuklarda Diş Çürüğü Tedavisi Sonrası Yaşam Kalitesindeki Değişimlerin Değerlendirilmesi}

\author{
(D) Kadriye Görkem Ulu Güzel ${ }^{1}$, (1) Müge Daloğlu² , (1) Işıl Sönmez ${ }^{1}$ \\ ${ }^{1}$ Aydın Adnan Menderes University Faculty of Dentistry, Department of Pediatric Dentistry, Aydın, Turkey \\ ${ }^{2}$ Istanbul Bağcılar Oral and Dental Health Center, Department of Pediatric Dentistry, İstanbul, Turkey
}

Keywords

Quality of life, dental caries, $\mathrm{CPO}_{8-10}$

Anahtar Kelimeler

Yaşam kalitesi, diş çürüğü, $\mathrm{CPO}_{8-10}$

Received/Geliş Tarihi : 11.12.2017

Accepted/Kabul Tarihi : 04.02.2018

doi:10.4274/meandros.96158

Address for Correspondence/Yazışma Adresi: Kadriye Görkem Ulu Güzel MD,

Aydın Adnan Menderes University Faculty of Dentistry, Department of Pediatric Dentistry,

Aydın, Turkey

Phone : +90 5057646372

E-mail : gorkemulu@yahoo.com

ORCID ID: orcid.org/0000-0002-3129-8490

(C) Meandros Medical and Dental Journal, Published by Galenos Publishing House.

This is article distributed under the terms of the

Creative Commons Attribution NonCommercial 4.0

International Licence (CC BY-NC 4.0).

\begin{abstract}
Objective: Various instruments can be used in children to determine the impact of Oral Health Related Quality of Life (OHROoL). Child Perceptions Questionnaire $\left(\mathrm{CPO}_{8-10}\right)$ can be used to evaluate the oral symptoms, functional limitations, emotional well-being and social well-being of subjects. Our study aimed at evaluating the impact of dental caries on OHRQoL and the changes in quality of life of subjects after treatment of dental caries compared to subjects without dental caries using $\mathrm{CPO}_{8-10}$.

Materials and Methods: Study included a total of 200 systemically healthy subjects aged 8-10 years (110 girls, 90 boys; 9.10 \pm 0.8 ) who referred to Adnan Menderes University Pediatric Dentistry clinic between June 2016 and May 2017. Based on the results of clinical and radiological examination, two groups were created consisting of subjects with $(n=100,9.14 \pm 0.81)$ and without $(n=100,9.05 \pm 0.82)$ dental caries and treatment needs, and $\mathrm{CPO}_{8-10}$ questionnaire was used to evaluate the quality of life. Questionnaire was repeated 4 weeks after the completion of treatment of subjects with dental caries. Results were subjected to statistical evaluation.

Results: Pre-treatment $\mathrm{CPO}_{8-10}$ scores of subjects with dental caries were higher than those of subjects without dental caries $(17.46 \pm 11.66$ and $6.86 \pm 4.76$, respectively; $\mathrm{p}<0.001) \mathrm{OHQoL}$ scores were decreased after dental treatment $(4.06 \pm 5.40)$ and the difference was statistically significant $(p<0.001) . \mathrm{CPO}_{8-10}$ scores after dental treatment were lower than those of subjects without dental caries who did not need treatment $(p<0.001)$.

Conclusion: We have determined that the untreated dental caries negatively affect the quality of life in children aged 8-10 years, and the quality of life substantially improves after treatment of dental caries.
\end{abstract}

Öz

Amaç: Ağız sağlığının yaşam kalitesi üzerine etkisinin Oral Health Related Quality of Life (OHROoL) belirlenmesi için çocuklarda farklı ölçekler uygulanabilmektedir. "Çocuk Algıları Ölçeği" [Child Perceptions Questionnaire" $\left(\mathrm{CPO}_{8-10}\right)$ ] ile gönüllülerin ağız içi semptomları, fonksiyonel kısıtlılıkları, duygusal problemleri ve sosyal etkiler değerlendirilebilmektedir. Çalışmamızda diş çürüğünün OHROoL üzerine etkisinin değerlendirilmesi, diş çürüklerinin tedavisi sonrasında yaşam kalitesindeki değişimlerinin $\mathrm{CPO}_{8-10}$ ile diş çürüğü olmayan gönüllülerle karşılaştırılması amaçlanmıştır.

Gereç ve Yöntemler: Adnan Menderes Üniversitesi Diş Hekimliği Pedodonti Kliniği'ne, Haziran 2016-Mayıs 2017 tarihleri arasında başvuran 8-10 yaş arasındaki 


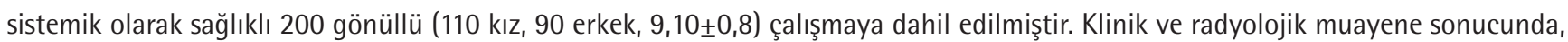
diş çürüğü ve tedavi intiyacı olan $(n=100,9,14 \pm 0,81)$ ve diş çürüğü ve tedavi ihtiyacı olmayanlardan $(n=100,9,05 \pm 0,82)$ oluşan iki grup oluşturulmuş ve yaşam kalitesinin değerlendirilmesinde $\mathrm{CPO}_{8-10}$ anketi uygulanmıştır. Diş çürüğü olan gönüllülerin, tedavilerinin tamamlanmasından 4 hafta sonra anket tekrarlanmıştır. Sonuçlar istatistiksel olarak değerlendirilmiştir.

Bulgular: Diş çürüğü bulunan gönüllülerin tedavi öncesi $\mathrm{CPO}_{8-10}$ skorları $(17,46 \pm 11,66)$ diş çürüğü olmayanlara $(6,86 \pm 4,76)$ göre daha yüksek bulunmuştur $(p<0,001)$. Diş tedavileri sonrasında, yaşam kalitesi skorları $(4,06 \pm 5,40)$ düş̧̋̈ş göstermiştir ve bu fark istatistiksel olarak anlamlıdır. $(\mathrm{p}<0,001)$. Diş tedavisi sonrasındaki $\mathrm{CPO}_{8-10}$ skorları, tedavi ihtiyacı olmayan çürüksüz gönüllülerden daha düşük olarak tespit edilmiştir $(p<0,001)$.

Sonuç: Sekiz-on yaş aralığındaki çocuklarda tedavi edilmemiş diş çürüğünün yaşam kalitesini olumsuz yönde etkilediği ve diş çürüklerinin tedavi edilmesi sonrasında yaşam kalitesinin önemli derecede arttığı belirlenmiştir.

\section{Introduction}

Oral and dental health problems may cause negative effects on functional, social and psychological status of children. Evaluation of impact of oral and dental health on quality of life of children can improve the communication between patients, parents and dentists. In addition, evaluation of Oral HealthRelated Quality of Life (OHRQoL) may be helpful in assessing the treatment needs, setting the priorities and assessing the outcomes of treatment strategies and initiatives (1).

Assessments have been conducted in recent years to investigate the impacts of dental caries, traumatic dental injuries, gingival diseases and malocclusions on quality of life in children (2-4). Various questionnaires and scales have been used to conduct such assessments. Early Childhood Oral Health Impact Scale (ECOHIS) is a method that is applied to children aged 2-5 years and responded by the parents (5). Oral Impact on Daily Performance scale evaluates the impacts of oral and dental health on daily activities (6). Child Perceptions Questionnaire (CPQ), which was also used in our study, was developed by Jokovic et al. (7) in 2004. This questionnaire can be applied to two different age groups of 8-10 years and 11-14 years. $\mathrm{CPQ}$ questionnaires, which contain questions that evaluate the functional, emotional, social and oral symptoms, have been adapted to many languages and found to be successful in determining OHRQoL (8-11).

Studies performed using $\mathrm{CPQ}_{8-10}$ questionnaire have shown that the dental caries negatively affect the quality of life in children $(12,13)$. The aim of our study was to determine if treatment of dental caries eliminated such negative effects, using $C P Q_{8-10}$ questionnaire.

\section{Materials and Methods}

Our study was conducted at Adnan Menderes University Faculty of Dentistry. Ethics committee's approval was obtained (Adnan Menderes University, Faculty of Medicine, Non-Interventional Ethics Committee/2016-876) before initiation of the study. The $\mathrm{CPQ}_{8-10}$ was used to evaluate OHRQoL in both groups. Questionnaire consisted of 25 questions including 5 questions for oral symptoms, 5 questions for functional, 5 questions for emotional and 10 questions for social status. Questions were directly asked to children and they were asked to respond the questions as "never", "a few times", "sometimes", "often" and "almost every day". Responses were scored between 0 and 4 according to 5-point Likert scale. Besides these 25 questions, the following 2 questions were also asked to children to obtain a general evaluation about their oral health: "What do you think about your mouth and teeth?" and "How often do you feel uncomfortable with your mouth and teeth?" (Questions 26 and 27). Study included 200 children aged 8-10 years who referred to pediatric dentistry clinic for examination between June 2016 and May 2017. Three calibrated dentists carried out the dental examinations. Based on the results of clinical and radiological examination, two groups were created consisting of subjects with dental caries who have no pain last 4 week, have no need radicular pulpal treatments and only need restorative dental treatment $(n=100)$ and without $(n=100)$ dental caries, and $\mathrm{CPQ}_{8-10}$ was used to evaluate the quality of life. Age, gender, health insurance status and income levels were also recorded in addition to questions evaluating the quality of life. Status of dental caries was reported as decayed, missing and filled teeth (DMFT)/dft, decayed-missing-filled surfaces (DMFS)/ $\mathrm{dfs}$ in consequence of clinical examination. 
Following the completion of clinical examination and questionnaire, treatment of patients with dental caries was initiated by a single specialist (MD). Oral hygiene training were given to patients after completion of preventive treatments and asked to return to clinic for control visit 4 weeks for repeating the questionnaire by two different specialist (KUGG and IS). All patients included were informed aboult the study.

\section{Statistical Analysis}

Data of group of healthy subjects and pre and post-treatment data of patients with dental caries were recorded and statistically evaluated by IBM SPSS Statistics 21.0 program (Armonk, NY, USA). Results were evaluated using chi-square test, Mann-Whitney $\mathrm{U}$ and Kruskal-Wallis tests.

\section{Results}

Records of 110 girls and 90 boys included in two groups consisting of subjects with $(n=100$, age $=$ $9.14 \pm 0.81$ year) and without $(n=100$, age $=9.05 \pm 0.82$ year) dental caries and treatment needs were evaluated. No statistically significant relationship was found between the age, gender, social insurance status and the OHRQoL; however, OHRQoL was observed to increase with the increase in income level and a statistically significant relationship was found $(p=0.017)$ (Table 1$)$. In group of patients with dental caries, mean DMFT/dft and mean DMFS/dfs values were calculated to be $2.51 \pm 1.99$ ve $3.62 \pm 2.53$ and $3.62 \pm 3.39$ ve $7.39 \pm 5.97$, respectively.

$\mathrm{CPQ}_{8-10}$ values of groups caries free and dental caries pretreatment and post-treatment were found to be $6.86 \pm 4.76,17.46 \pm 11.66$ and $4.06 \pm 5.4$, respectively (Table 2). When the responses to Questions 26 and 27 were evaluated, the mean values were determined to be $1.64 \pm 0.905,1.08 \pm 0.849$ and $1.82 \pm 0.657$ and $1.31 \pm 0.961,1.71 \pm 0.891$ and $43 \pm 0.537$, respectively in caries free, dental caries pretreatment and posttreatment subjects (Table 3 ).

\section{Discussion}

Most of the current OHRQoL instruments could manage to measure the impact of oral health on physical, functional, social and emotional well-being of a person. As in adults, oral and dental health disorders can affect diet, health and quality of life in children (14). Results of our study also showed that the oral and dental health affect quality of life. A significant difference was observed between the OHRQoL values of caries free children and children with dental caries, and dental caries were determined to negatively affect the quality of life. According to results of our study, quality of life is not affected by age, gender and health insurance status.

\begin{tabular}{|c|c|c|c|c|}
\hline & Caries free subjects ( $n$ ) & Subjects with dental caries $(\mathrm{n})$ & Total & Rate (\%) \\
\hline \multicolumn{5}{|l|}{ Age } \\
\hline 8 & 31 & 27 & 58 & 29.0 \\
\hline 9 & 33 & 32 & 65 & 32.5 \\
\hline 10 & 36 & 41 & 77 & 38.5 \\
\hline \multicolumn{5}{|l|}{ Gender } \\
\hline Girls & 55 & 55 & 110 & 55.0 \\
\hline Boys & 45 & 45 & 90 & 45.0 \\
\hline \multicolumn{5}{|l|}{ Income level } \\
\hline TRY $<1.000$ & 13 & 22 & 35 & 17.5 \\
\hline TRY 1.000-2.999 & 48 & 60 & 108 & 54.0 \\
\hline TRY 3.000-5.999 & 25 & 14 & 39 & 19.5 \\
\hline TRY $>6.000$ & 14 & 4 & 18 & 9.0 \\
\hline \multicolumn{5}{|l|}{ Health insurance } \\
\hline Yes & 95 & 94 & 189 & 94.5 \\
\hline No & 5 & 6 & 11 & 5.5 \\
\hline
\end{tabular}


Table 2. Study groups and oral health related quality of life values $(p<0.001)$

\begin{tabular}{|c|c|c|c|}
\hline & Caries free & Dental caries pretreatment & $\begin{array}{l}\text { Dental caries } \\
\text { Post-treatment }\end{array}$ \\
\hline $\begin{array}{l}\text { Oral symptoms } \\
\text { (Questions 1-5) }\end{array}$ & $2.50 \pm 2.24 b$ & $5.75 \pm 2.88 c$ & $0.91 \pm 1.34 a$ \\
\hline $\begin{array}{l}\text { Functional limitations } \\
\text { (Questions 6-10) }\end{array}$ & $1.31 \pm 1.60 \mathrm{~b}$ & $4.08 \pm 3.50 c$ & $0.89 \pm 1.33 a$ \\
\hline $\begin{array}{l}\text { Emotional well-being } \\
\text { (Questions 11-15) }\end{array}$ & $1.89 \pm 2.31 b$ & $4.59 \pm 4.64 b$ & $1.13 \pm 2.25 \mathrm{a}$ \\
\hline $\begin{array}{l}\text { Social well-being } \\
\text { (Questions 16-25) }\end{array}$ & $1.15 \pm 1.88 \mathrm{a}$ & $3.17 \pm 4.56 \mathrm{~b}$ & $1.17 \pm 2.32 \mathrm{a}$ \\
\hline $\begin{array}{l}\text { Total } \\
\text { (Questions 1-25) }\end{array}$ & $6.86 \pm 4.76 b$ & $17.46 \pm 11.66 c$ & $4.06 \pm 5.40 \mathrm{a}$ \\
\hline
\end{tabular}

Table 3. Responses to questions 26 and 27 and mean values by groups

\begin{tabular}{|l|l|l|l|} 
& Caries free & Dental caries pre-treatment & Dental caries post-treatment \\
\hline Question 26 & $1.64 \pm 0.90 \mathrm{~b}$ & $1.08 \pm 0.84 \mathrm{a}$ & $1.82 \pm 0.65 \mathrm{c}$ \\
\hline Question 27 & $1.31 \pm 0.96 \mathrm{~b}$ & $1.71 \pm 0.89 \mathrm{c}$ & $0.43 \pm 0.53 \mathrm{a}$ \\
\hline a,b,c: A statistically significant differences is shown with the letter a, b, c in the same column \\
\hline
\end{tabular}

Children of parents with higher education and family income levels are likely to have a better quality of life. It has been shown that lower education level causes decreased income (15) and the low income level is associated with poverty (16). Children from poor families have limited access to healthcare services and preventive interventions that avoid poor quality of life (17). Results of our study indicated a significant relationship between family income level and quality of life. Children from families with higher income level were observed to have a superior quality of life.

Untreated dental caries in children can cause difficulties in chewing, sleeping and socializing, and affect self-confidence, growth and weight gain, thereby decreasing quality of life (18). Such effect of dental caries has given rise to investigations into whether dental treatments could improve the quality of life again. In recent years, investigators evaluated pre- and post-treatment quality of life of children given dental treatment under general anaesthesia using ECOHIS scale, and reported that dental treatment positively affected the quality of life (19-21). These studies were usually conducted in patients aged 6 years and below. In a study conducted in an older age group by administering treatment under clinical conditions, $\mathrm{CPQ}_{8-10}$ questionnaire was applied to a total of 186 children divided into 2 groups as healthy children and children with dental caries. Questionnaire was repeated 4 weeks after the completion of treatment in patients who needed treatment. Based on the results of study, it was concluded that the treatment of dental caries positively affected the quality of life (22). These results are consistent with the results of our study.

\section{Study Limitations}

Our study showed that the post-treatment OHRQoL values were significantly higher compared to group of healthy subjects. This difference might be associated with the resolution of pre-treatment symptoms such as pain and dental fear and the reduction of anxiety.

Orthodontic problems are also known to affect quality of life. Healey et al. (23) evaluated the relationship between malocclusion and the quality of life using $\mathrm{CPQ}_{11-14}$ questionnaire and reported a significant relationship between them. Orthodontic evaluations were not conducted in subjects with and without dental caries in our study, and the patients presented to our clinic with orthodontic problems were asked to complete the questionnaire without receiving orthodontic treatment. This might have affected the OHRQoL values and can be considered as a limitation of our study. 
As another limitation, the relationship between treatment type and the quality of life could not be evaluated in our study. More traumatic procedures like tooth extraction and the number of such procedures are believed to increase the possibility of problems such as post-treatment eating difficulty in children (24). On the other hand we did not evaluate the validity of $\mathrm{CPQ}_{8-10}$ in Turkish children. During the development and evaluation of the CPQ for 8- to 10-year-olds, questions were selected from the $\mathrm{CPQ}_{11-14}$ (7). The translation and validation of $\mathrm{CPQ}_{11-14}$ version into Turkish was carried out by Aydogan (25). The $\mathrm{CPQ}_{8-10}$ was used to evaluate OHRQoL in both groups. We approved the validation of $\mathrm{CPQ}_{11-14}$ version into Turkish children for assesing the 8-10 years old. Further studies are needed to development of the $\mathrm{CPQ}_{8-10}$ in Turkish children for more accurate estimation.

\section{Conclusion}

Our study has shown that the quality of life of 8 to 10-years-old children with dental caries that need to be treated is negatively affected compared to children without dental caries and treatment needs, and the quality of life is significantly improved after treatment. Thus, it appears that the dental treatments are likely to improve the quality of life in children.

\section{Ethics}

Ethics Committee Approval: Adnan Menderes University Faculty of Medicine, Non-Interventional Ethics Committee, (approval number: 2016-876).

Informed Consent: All patients included were informed about the study.

Peer-review: Externally peer-reviewed.

\section{Authorship Contributions}

Surgical and Medical Practices: K.G.U.G., M.D., Concept: K.G.U.G., I.S., Design: K.G.U.G., I.S., Data Collection or Processing: K.G.U.G., M.D., Analysis or Interpretation: K.G.U.G., M.D., Literature Search: K.G.U.G., M.D., Writing: K.G.U.G., M.D., I.S.

Conflict of Interest: No conflict of interest was declared by the authors.

Financial Disclosure: This project was supported by Adnan Menderes University, Scientific Research Projects Coordination Unit Number: 2016/DHF-16001.

\section{References}

1. Gilchrist F, Rodd H, Deery C, Marshman Z. Assessment of the quality of measures of child oral health-related quality of life. BMC Oral Health 2014; 23: 14-40.

2. Tomazoni F, Zanatta FB, Tuchtenhagen S, da Rosa GN, Del Fabro JP, Ardenghi TM. Association of gingivitis with child oral healthrelated quality of life. J Periodontol 2014; 85: 1557-65.

3. Patel N, Hodges SJ, Hall M, Benson PE, Marshman Z, Cunningham SJ. Development of the Malocclusion Impact Questionnaire (MIQ) to measure the oral health-related quality of life of young people with malocclusion: part 1 - qualitative inquiry. Journal of Orthodontics 2016; 43: 7-13.

4. Bendo CB, Paiva SM, Varni JW, Vale MP. Oral health-related quality of life and traumatic dental injuries in Brazilian adolescents. Community Dent Oral Epidemiol 2014; 42: 216-23.

5. Martins-Júnior PA, Vieira-Andrade RG, Corrêa-Faria P, OliveiraFerreira F, Marques LS, Ramos-Jorge ML. Impact of early childhood caries on the oral health-related quality of life of preschool children and their parents. Caries Res 2013; 47: 211-8.

6. Gherunpong S, Tsakos G, Sheiham A. Developing and evaluating an oral health-related quality of life index for children; the CHILD-OIDP. Community Dent Health 2004; 21:1 61-9.

7. Jokovic A, Locker D, Tompson B, Guyatt G. Questionnaire for measuring oral health-related quality of life in eight- to ten-yearold children. Pediatr Dent 2004; 26: 512-8.

8. McGrath C, Pang HN, Lo EC, et al. Translation and evaluation of a Chinese version of the Child Oral Health-related Quality of Life measure. Int J Paediatr Dent 2008; 18: 267-74.

9. Barbosa TS, Tureli MC, Gaviao MB. Validity and reliability of the Child Perceptions Questionnaires applied in Brazilian children. BMC Oral Health 2009; 9: 13.

10. Bekes K, John MT, Zyriax R, Schaller HG, Hirsch C. The German version of the Child Perceptions Questionnaire (CPQ-G11-14): translation process, reliability, and validity in the general population. Clin Oral Investig 2012; 16: 165-171.

11. Brown A, Al-Khayal Z. Validity and reliability of the Arabic translation of the child oral-healthrelated quality of life questionnaire (CPQ11-14) in Saudi Arabia. Int J Paediatr Dent 2006; 16: 405-11.

12. Do LG, Spencer AJ. Evaluation of oral health-related quality of life questionnaires in a general child population. Community Dent Health. 2008; 25: 205-10.

13. Shin HS, Han DH, Shin MS, Lee HJ, Kim MS, Kim HD. Korean version of child perceptions questionnaire and dental caries among Korean children. PLoS One 2015; 10: e0116011.

14. Barbosa TS, Gaviao MB. Oral health-related quality of life in children: part II: effects of clinical oral health status: a systematic review. Int J Dent Hyg 2008; 6: 100-7.

15. Sanders AE, Spencer AJ. Childhood circumstances, psychosocial factors and the social impact of adult oral health. Community Dent Oral Epidemiol 2005; 33: 370-7.

16. Piovesan C, Antunes IL, Guedes RS, Ardenghi TM. Impact of socioeconomic and clinical factors on child oral health-related quality of life (COHRQoL). Qual Life Res 2010; 19: 1359-66. 
17. Paula JS, Leite IC, Almeida AB, Ambrosano GM, Pereira AC, Mialhe $\mathrm{FL}$. The influence of oral health conditions, socioeconomic status and home environment factors on schoolchildren's selfperception of quality of life. Health Qual Life Outcomes 2012; 10: 6 .

18. Martins-Júnior PA, Ramos-Jorge J, Paiva SM, Marques LS, Ramos-Jorge ML. Validations of the Brazilian version of the Early Childhood Oral Health Impact Scale (ECOHIS). Cad Saude Publica 2012; 28: 367-74.

19. Jankauskiene B, Virtanen JI, Kubilius R, Narbutaite J. Oral healthrelated quality of life after dental general anaesthesia treatment among children: a follow-up study. BMC Oral Health 2014; 1: 1481.

20. Almaz ME, Sönmez IS, Oba AA, Alp S. Assessing changes in oral health-related quality of life following dental rehabilitation under general anesthesia. J Clin Pediatr Dent 2014; 38: 263-7.

21. Cantekin K, Yıldırım MD, Cantekin I. Assessing change in quality of life and dental anxiety in young children following dental rehabilitation under general anesthesia. Pediatr Dent 2014; 36: 12E-17E.

22. de Paula JS, Sarracini KL, Meneghim MC, Pereira AC, Ortega EM, Martins NS, et al. Longitudinal evaluation of the impact of dental caries treatment on oral health-related quality of life among schoolchildren. Eur J Oral Sci 2015; 123: 173-8.

23. Healey DL, Gauld RD, Thomson WM. Treatment-associated changes in malocclusion and oral health-related quality of life: A 4-year cohort study. Am J Orthod Dentofacial Orthop 2016; 150: 811-7.

24. Knapp R, Gilchrist F, Rodd HD, Marshman Z. Change in children's oral health-related quality of life following dental treatment under general anaesthesia for the management of dental caries: a systematic review. Int J Paediatr Dent 2017; 27: 302-12.

25. Aydogan C, Impact of Personality Traits and Optimism on the oral health related quality of life of children with malocclusion, Yüzüncü Yıl University Institute of Health Sciences Department of Orthodontics, Phd Thesis, Van 2015. 